\title{
AN OVERVIEW OF THE RULE OF LAW VALUES WITHIN MALAYSIA'S ANTI-TERROR LAW: \\ A LEGAL PERSPECTIVES FROM INDIA AND THE UNITED KINGDOM
}

\author{
Ho Peng Kwang \\ Faculty of Law \\ Universiti Malaya, Kuala Lumpur \\ E-mail: richo@siswa.um.edu.my \\ Johan Shamsuddin Sabaruddin \\ Faculty of Law \\ Universiti Malaya, Kuala Lumpur \\ E-mail: johans@um.edu.my \\ Saroja Dhanapal \\ Faculty of Law \\ Universiti Malaya, Kuala Lumpur \\ E-mail: saroja.dhanapal@um.edu.my
}

\begin{abstract}
Changes in the legislative framework in response to terrorist threats in Malaysia, India and the United Kingdom since the 9/11 attacks have witnessed the integration of national security issues and criminal justice to form part of the extraordinary security laws passed by the authorities. This integration has rested on the premise that terrorism is an unprecedented threat and so it requires legislation tailored to what has been called as a "new paradigm in prevention. The criminal law has largely, though not exclusively, focused only on dealing with crimes that have already taken place. However, the reason for the shift in states emphasis towards prevention in counter-terrorism is that terrorism is an extraordinary threat that calls for a special response. A unique theme of most anti-terror legislations is focusing on what is referred to by the government as 'prevention'- hoping to foil foreseeable attacks from the terrorists. However, the key concern is the impact on the Rule of Law values when applying the anti-terror laws. This article argues that the preventive methods adopted by Malaysia, India and the United Kingdom are effective in forestalling terrorist activities to a certain extent, but often this comes at a high price to pay when individual human rights are sacrificed along the way. Further, anti-
\end{abstract}


terror legislation has degraded the Rule of Law values in response to terrorism threat or national security.

Keywords: Rule of Law, Terrorism; National security; Preventive detention; POTA 2015.

Abstrak: Perubahan dalam struktur perundangan sebagai tindak balas kepada ancaman keganasan di negara seperti Malaysia, India dan United Kingdom selepas serangan 9/11 menyaksikan isu keselamatan negara dan undang-undang jenayah telah diintegrasikan untuk membentuk satu undang-undang keselamatan baharu yang agak luar biasa yang diiktiraf oleh pihak berkuasa. Integrasi ini berlandaskan premis bahawa keganasan ialah satu ancaman yang dipandang serius dan memerlukan undang-undang yang bersesuaian untuk membendungnya yang dirujuk sebagai satu 'paradigma baharu pencegahan'. Pada lazimnya, undang-undang jenayah hanya tertumpu kepada menangani jenayah yang telah berlaku dan tidak memberi tumpuan kepada jenayah yang bakal dilakukan oleh pengganas. Oleh sebab itu, satu perubahan telah dilihat apabila penekanan terhadap pencegahan dalam membendung keganasan olehnegara-negara yang dikaji adalah kerana keganasan dianggap sebagai ancaman luar biasa dan memerlukan tindak balas khas. Dalam undang-undang antikeganasan, tema unik yang diberi perhatian oleh kerajaan adalah kepada langkah pencegahan - dengan harapan ia dapat mematahkan cubaan serangan yang dirancang oleh pihak pengganas. Walau bagaimanapun, keprihatinan utama ialah kesan ke atas peraturan Undang-undang apabila undang-undang antikeganasan dilaksanakan. Artikel ini berpendapat bahawa kaedah pencegahan yang diterima pakai oleh negara seperti Malaysia, India dan United Kingdom berkesan dalam menghalang kegiatan pengganas pada tahap tertentu, tetapi malangnya selalu melibatkan pengorbanan hak asasi individu. Tambahan pula, undang-undang antikeganasan telah menggugat nilai-nilai peraturan undang-undang susulan daripada tindak balas yang diambil terhadap ancaman daripada keganasan atau untuk keselamatan negara.

Kata Kunci: Peraturan undang-undang; Keganasan; Keselamatan negara; Tahanan pencegahan; POTA 2015. 


\section{INTRODUCTION}

The Rule of Law is inherently a debatable theory. It implies different things to different people and brings forth a vast array of political agendas. Raz's narrative of the Rule of Law is, thus far, the most influential in modern times. Raz describes "the basic intuition" underlying the principle of the Rule of Law to be: "the law must be able to regulate the conduct of its subjects." According to Raz, the law must be "prospective, general, clear, public, and relatively stable." Besides that, Raz also included an independent judiciary and fair hearings without bias, which are the primary focus of this article. Predominantly, the Rule of Law is concerned about constitutional liberty. However, the Malaysian anti-terror law such as the Prevention of Terrorism Act, 2015 (POTA 2015) seems to disregard all the ideals of the Rule of Law.

Before embarking on discussing the operation and the challenges of anti-terror legislation in Malaysia, and whether the laws degrade the Rule of Law values or not, it is essential to explore the historical aspects of the security laws enacted prior to the latest anti-terror law vis-a-vis the Prevention of Terrorism Act, 2015 ('POTA 2015'). In Malaysia, the state of emergency was declared on 31 July 1960 by introducing the preventive detention regime under the now repealed Act known as the Internal Security Act, 1960 ('ISA 1960'). Although the government subdued the state of emergency, the preventive detention regime under ISA 1960 was maintained by the authority as a potent tool against internal security threats subsequently. With ISA 1960, the government continued to enjoy powers to detain persons assessed as harmful to the national security of Malaysia, with somewhat broad powers to curb the freedom of expression, association, and the press. When the late Tun Abdul Razak, the then Deputy Prime Minister presented the ISA Bill in the Parliament, he said this, "Let me make it quite clear that it is no pleasure for the Government to order the detention of any person. Nor will these powers be abused." 2 (Emphasis added) However, during the 52 years when ISA 1960 was in force, the government systematically turned the law to suppress political dissent. In the early 1980s, Prime Minister,

Raz, J. (1979). The authority of law (1st ed.). Oxford: Clarendon Press., p. 214.

2 Parliamentary Debates, Dewan Rakyat (21.6.1960), at p. 1189 
Mahathir Mohammad, expressed his view of ISA 1960 shortly after he took over the post. At that time, the public hoped that the use of preventive detention orders would diminish under the leadership of Mahathir. However, political trouble in 1987 saw another revival of these preventive detention measures which were extensively applied by the government as reliable measures to suppress political protests. In October 1987, the police arrested 106 people in the infamous "Operation Lalang", comprising prominent leaders and opposition lawmakers, who were jailed without charge under ISA $1960 .{ }^{3}$

In 2001, a High Court judge recommended the Parliament to examine ISA 1960 and to minimise its abuses. ${ }^{4}$ Shortly after the judgement of Abdul Ghani Haroon, in May 2001, local human rights groups launched the "Abolish ISA Movement" which comprised 82 nongovernmental organisations to pressure for the abolition of ISA 1960. The 9/11 terrorist attacks in New York further stifled this "Abolish ISA Movement" and gave a good excuse for the government to further extend the detention without charge of terrorism suspects and non-suspects based on a broad interpretation of the security offence in ISA 1960. In three separate sweeps soon after 9/11, the government detained militants with alleged links to Kumpulan Militan Malaysia ('KMM'). Twenty-two suspects were also alleged to be associated with Jemaah Islamiah ('JI'), a radical group that sought to validate an Islamic Union of Malaysia, Mindanao and Indonesia. ${ }^{5}$ These arrests coincided with the capture of $13 \mathrm{JI}$ militants in Singapore. ${ }^{6}$ Fearing threats from Islamic radicals, usually, the citizens were more eager to allow the government to have the power to seize and detain whomever it believed was linked to KMM, JI or even merely opposition parties. While it is unproven whether some of these detainees sought to carry out terrorist acts, $9 / 11$ gave the government more political power to exploit the situation.

3 “Operation Lalang Revisited. (2016)". Aliran.com. Retrieved 5 November 2016, from http://aliran.com/oldsite/hr/js3.html

4 Abdul Ghani Haroon v Ketua Polis Negara and Anor. (2001) 2 CLJ 709

5 "Malaysia reveals militant link to arrests - January 23, 2002." Edition.cnn. com. Retrieved 5 November 2016, from http:/edition.cnn.com/2002/WORLD/ asiapcf/southeast/01/23/malaysia.muslim.arrest/index.html

6 "Press Releases Singapore Government Press Statement on ISA Arrests," 11 January 2002. Mha.gov.sg. Retrieved 5 November 2016, from <https://www. mha.gov.sg/Newsroom/press-releases/Pages/Singapore $\% 20$ Government $\% 20$ Press\%20Statement\%20On\%20ISA\%20Arrests,\%2011\%20January\%202002. aspx $>$ 
Finally, in 2012, the draconian ISA 1960 was finally repealed by introducing the Security Offences (Special Measures) Act 2012 ('SOSMA 2012'). Although SOSMA 2012 was enacted to address broad security offences, and not specific terrorism cases per $\mathrm{e}^{7}$ The

controversial indefinite preventive detention without trial like the ones in ISA 1960 is no longer available under SOSMA 2012. All new security offence detainees caught by the police under this Act will be accorded proper trials in the High Court. ${ }^{8}$ SOSMA dictates that a detainee must be brought to the High Court and charged with an offence after 28 days of detention. This is in direct contrast with ISA 1960, where there was no requirement that a person be charged nor tried for any offence. In fact, the Human Rights Commission of Malaysia (Suhakam) has lauded the move taken by the government to replace the much controversial ISA 1960 with SOSMA 2012. ${ }^{9}$ Unfortunately, the advent of POTA 2015 in response to UN Resolution 2178 brought the preventive detention regime to the fore again which led one of its strong proponents to claim POTA 2015 was like a twin of ISA. ${ }^{10}$

\section{Preventive Detention Orders under POTA 2015}

Without a doubt, preventive detention is a counter-terrorism tool that brings a grave risk of abuse because of the conceptual and procedural flaws relating to its practice. While many states felt it is a crucial and effective counter-terrorism tool, others have expressed

\footnotetext{
7 The preamble of SOSMA 2012 states: "it is necessary to stop action by a substantial body of persons both inside and outside Malaysia: 1) to cause, or to cause a substantial number of citizens to fear organized violence against persons or property; 2) to excite disaffection against the Yang di-Pertuan Agong; 3) which is prejudical to public order in, or the security of, the Federation or any part thereof; or 4) to procure the alteration, otherwise than by lawful means, of anything by law established."

8 See Section 12 of SOSMA 2012.

9 "Security Offences Bill a positive step, says Suhakam" - Nation | The Star Online. (2012). Retrieved on 5 November 2016, from http://www.thestar. com.my/news/nation/2012/04/16/security-offences-bill-a-positive-step-sayssuhakam/

10 "Prevention of Terrorism Bill a welcomed conjoined twin to ISA, says Perkasa" - The Rakyat Post. (2015). Retrieved 5 November 2016, from http://www. therakyatpost.com/news/2015/03/31/prevention-of-terrorism-bill-a-welcomedconjoined-twin-to-isa-says-perkasa/
} 
certain concerns. For example, the counter-terrorism context of preventive detention refers to the future act, which is impossible to predict with complete accuracy and presents a risk of detaining innocent people. ${ }^{11}$ The prediction problem is not exclusive to the terrorism context, it applies equally to other sources of preventive detention powers in Malaysia, especially those preventive detentions without charge under the Emergency (Public Order and Prevention of Crime) Ordinance 1969 (Emergency Ordinance) (repealed), the Dangerous Drugs (Special Preventive Measures) Act 1985 (Dangerous Drugs Act) ${ }^{12}$ and the Prevention of Crime Act 1959. Under these preventive laws, police can detain suspected gang members and criminals who cannot be formally charged owing to lack of evidence, and suspected drug traffickers. The preventive detention regimes in the two Acts are analogous to the preventive detention under POTA 2015. It is observed that the term preventive detention has been used by various countries and writers in several contexts, as administrative detention, ${ }^{13}$ investigative detention,,${ }^{14}$ pre-charge detention or ministerial detention. ${ }^{15}$ While there seems to be no universally accepted definition of "preventive detention" under international law, basically preventive detention regimes can be divided into three broad classifications, namely detention under the immigration laws, internal security detentions and the pre-trial detention. The three categories vary in several aspects, including the legal grounds for detention, notice of the framed charges, requirement to appear before a regulatory authority, the duration of detention, the right to have access to lawyers, the right to a fair and

11 Cole, D. (2009). Out of the shadows: Preventive detention, suspected terrorists, and war. California Law Review, 97(3), 693-750. At p.696.

12 Emergency (Public Order and Prevention of Crime) Ordinance 1969; Dangerous Drugs (Special Prevention Measures) Act 1985 (Act 316). The former was firstly introduced as a temporary measure to control the spread of violence after the May 13, 1969 racial riots, but has since been repealed. The latter was introduced with a sunset clause, under which the Act will be reviewed every five years. Since 1985, the Act has been successfully renewed from time to time.

13 Waxman, M. C. (2009). Administrative Detention of Terrorists: Why Detain, and Detain Whom? Columbia Public Law Research Paper, (08-190), 08-190.

14 Stigall, D. (2009). Counterterrorism and the comparative law of investigative detention. Cambria Press.

15 Steven Green, 'Chapter 2: Preventive Detention and Public Security - Towards A General Model' in Harding, A., \& Hatchard, J. (Eds.). (1993). Preventive Detention and Security Law: A Comparative Survey (Vol. 31). Martinus Nijhoff Publishers. 
public hearing, judicial review of the detention, and finally, the rules on interrogation during detention. Pre-trial detention is, in essence, a detention pending police inquiries. The police are empowered to detain any terror suspect for inquiries for up to 21 days in Malaysia. ${ }^{16}$ Such detentions orders may be made because there are grounds for believing the detainee is engaged in the commission or support of terrorist acts.

Under POTA 2015, a person may be held without trial for a term not exceeding 2 years if the Prevention of Terrorism Board ('PTB') is satisfied that the detention is needed in the interest of the security of Malaysia if the person is engaged in or supports terrorist acts; $;{ }^{17}$ or the PTB may issue a restriction order, and the person shall then be subjected to police supervision not exceeding a five-year period ${ }^{18}$ with certain conditions to observe. The detention and restriction period can be extended if the board determines there are valid grounds and if not, it can direct the person to be set free. If the restricted person violates the terms of the restriction order, he can be liable to a jail term not exceeding ten years and not less than two years. ${ }^{19}$ No hearing before the court of law is given to the terror suspect rather the order is issued directly by the PTB. Thus, the executive powers are no longer vested with the Home Minister, like in the ISA cases, but it has entrusted five members of the PTB with the tasks of determining the culpability of the detained person. Unlike in the past, involving ISA cases, the police decided whom to detain, but under POTA 2015, only the board is allowed to carry out such a decision.

Another significant legal observation here is that, under POTA 2015, a terrorism offence may not have been done as yet or is not accomplished at the point of arrest, but individuals would have been detained merely on reasonable suspicion as provided in the Act. ${ }^{20}$ This is termed as 'inchoate' offence under criminal law. It is further observed that under the Malaysian Penal Code, an individual attempt to commit a crime when they cause such an offence to be committed and in such an attempt does any act in committing such an offence. ${ }^{21}$ Offences like conspiracy, abetment and instigation

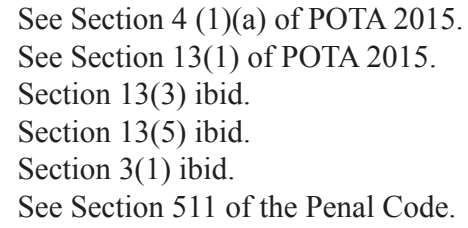


fall under this group. The rationale behind inchoate offence is to prevent a probable crime before it is crystallised-a proactive step in crime prevention. The terrorism offences under Chapter VIA of the Penal Code share the same sentiment of criminal acts carried out to prepare for a terrorist act. However, under POTA 2015, even at the formative stages of an action, for example, giving a speech can be deemed as an offence of 'supporting' although a terrorist act may not materialise or has yet to take place. This 'catch-all' offence may lead to individuals being penalised with detention even before any clear criminal intent can be established, bearing in mind there is no need for a court of law to establish that element of criminal intent under POTA 2015. In tackling terrorism, the Malaysian government seems to have preferred to act pre-emptively by capturing people before any clear intention to commit the terrorist act is established, an approach known as 'precautionary principle"22 but what is more problematic is the sweeping definition outlined in POTA 2015 that will give an extensive discretion for the authorities to make an arrest. Also, the preamble to POTA 2015 is unclear as to the precise circumstances in which the law may be applied and on what basis a person may be detained without charge. This is further confounded by the vague meaning of phrases like 'commission', 'support', 'involving' and 'engaged. ${ }^{23}$ Arguably, this may give rise to a person being detained without trial beyond the legitimate purposes of the Act. An examination of previous security cases brought to court showns the Malaysian High Court has pointed out a similar form of wide scope and vague context under the former repealed ISA 1960 whereby a person may be arbitrarily detained for security offences. For instance, in the case of Abdul Ghani Haroon v. Ketua Polis Negara and Anor, ${ }^{24}$ the High Court opined that the phrase "prejudicial to the security of Malaysia" is too general and vague in nature as found under section 73(1) (b) of the repealed ISA 1960. Justice Hishamudin Yunus, in the same case, said:

22 For review of this principle, see Sunstein, C. R. (2005). Laws of fear: Beyond the precautionary principle (Vol. 6). Cambridge University Press.

23 The preamble in POTA 2015 provides: "An act to provide for the prevention of the commission or support of terrorist acts involving listed terrorist organizations in a foreign country or any part of a foreign country and for the control of persons engaged in such acts and for related matters".

24 Abdul Ghani Haroon (ibid) n.4 
"If the arresting officer has reason to believe that the applicant (detainee) has acted or is about to act or is likely to act in a manner prejudicial to the security of Malaysia then the affidavit must state in what manner the applicant (detainee) has acted or is about to act or is likely to act in a manner prejudicial to the security of Malaysia. The court is not interested in detailed information. Some reasonable amount of particulars should be provided for the purpose of satisfying the court that there is some basis for the arrest and to enable the detainee who believes he is innocent to defend himself." (Emphasis added).

Apparently, with Abdul Ghani Haroon, the Malaysian High Court has treated vague statutory provisions with a more restricted scope of judicial interpretation in the past when dealing with security laws. This was a significant step taken by the Malaysian judiciary, but it is uncertain whether the broad language used for detention under the POTA 2015 will be read more narrowly like Abdul Ghani Haroon. It is important to know that nder POTA 2015, once a suspect is apprehended, the evidential burden rests on the suspect to prove that the preparatory activity did not progress further to cause a terrorist attack so as to avoid being detained by the authority. By shifting the burden of proof, it runs contrary to the basic criminal law system that everyone charged with a crime shall be presumed innocent until proven guilty. The criminalisation of preparatory terrorism offence and the shifting of the burden of proof is indeed unfair to the accused because a situation can arise when the prosecution holds materials that are helpful to the accused but are unwilling to disclose due to public interest consideration, especially in security offence cases. Hence, the accused's lawyer cannot conduct a proper defence in a trial. It is an indisputable axiom that a person accused of having committed a crime should receive a fair trial and, if he cannot be tried fairly for that offence, he should not be tried for it at all. The right to a fair trial is, therefore, a cardinal requirement of the Rule of Law. What must be recognised is that fairness means fairness to both sides, not just one. Under criminal law, the procedure followed must give a fair opportunity for the prosecutor and the accused to prove his case and to the accused to rebut it. However, with the advent of POTA 2015, not only the presumption of innocence has been compromised, it is also against the principle of natural justice on the right to have a fair hearing. 
Another issue of greater concern is that the period of the preventive detention order is not static. Depending on the decision made by the PTB, the duration of detention can be reduced to less than two years. However, the period of detention may also be renewed by the PTB for a further term of two years ${ }^{25}$ before the expiry each time on the same grounds or for reasons different from those on which the order was originally made, or partly on the same grounds and partly on different grounds. ${ }^{26}$ The most controversial part of extending the detention order is that there is no limit on the number of times an order may be extended. Thus, a detention order under POTA 2015 can be extended for an unlimited number of two-year periods, as long as the PTB decides to do so. ${ }^{27}$ Perhaps the power to impose or renew the detention of a person without limit is equivalent to an indefinite term of imprisonment considering the person has not been found guilty of any offence, be it major or minor. This is viewed as denigrating the principle of the Rule of Law. The argument that police needs an indefinite amount of time to remove terror threats posed by an individual is a fallacy. Although under certain circumstances, it may be acceptable that detention beyond a particular fixed period is necessary, such open-ended detention must not be adopted arbitrarily.

There is also another order that can restrict the freedom of movement of a person under POTA 2015, although that person is not confined in the detention centre. This is termed as a restriction order, and such order can be for any period not exceeding five years at a time. ${ }^{28}$ A restriction order may prevent a person from being outdoors between the times stated in the order; requiring him or her to notify the police of his movements at specified times; not to have access to the internet unless it is provided in the order, and an electronic monitoring device may be attached to him. Similar to the issuing and extension of the preventive detention order, a restriction order issued can be renewed for a further five years based on the same or different grounds, and there is also no limitation on the maximum period a restriction order can be extended each time on expiry. The restriction order is more like an in-house detention to be applied when the police see it as unnecessary to detain a person in a detention centre. The punishment for non-compliance of the conditions

\footnotetext{
25 Section 17(1) of POTA 2015.

26 Section 17(2) (a)-(c) ibid.

27 Section 17(5) ibid.

28 See Section 13(3) ibid.
} 
stipulated in the restrictive order can be severe. Any person found to have violated the order can be jailed up to maximum of ten years. ${ }^{29}$ From the preceding discussion, it can be observed that the detention order and its procedures introduced under POTA 2015 have deviated from the ordinary criminal law and procedure, especially on matters such as the arrest, detention and the required evidentiary burden. Such departure from the established principles of criminal law has affected individual freedom and rights which are repugnant to the Rule of Law principles.

\section{Legal perspective from other jurisdictions}

All governments have a legitimate interest in defending the public from any act of terrorism by taking pre-emptive steps to prevent them from occurring. However, the problem is that anti-terror law is particularly elusive because they circumvent the constitutional protection of basic human rights. As highlighted, Malaysia's antiterror law model is premised on pre-emptive rather than punitive nature under the ordinary criminal law system. An individual's freedom can be restricted merely by reasonable suspicion which is repugnant to the concept of the Rule of Law values. Other democratic nations like India and the United Kingdom have their own respective anti-terror laws too, and they have confronted many challenges in upholding the Rule of Law values, in particular, the curtailment of one's basic rights.

\section{India}

Section 57 of India's Criminal Procedure Code 1973 ('CrPC 1973') dictates that in the absence of a court order issued by a Magistrate, a suspect caught without a proper warrant is to be released immediately. ${ }^{30}$ However, India's anti-terror laws such as the Prevention of Terrorism Act, 2002 (POTA 2002) (repealed) and the current Unlawful Activities Prevention Act, 1967 ('UAPA 1967'),

$29 \quad$ Section 13 (5) ibid.

30 Section 57 CrPC provides: "Person arrested not to be detained more than twenty-four hours. No police officer shall detain in custody a person arrested without warrant for a longer period than under all the circumstances of the case is reasonable, and such period shall not, in the absence of a special order of a Magistrate under section 167, exceed twenty-four hours exclusive of the time necessary for the journey from the place of arrest to the Magistrate's Court" 
allow up to 180 days $^{31}$ of detention by disregarding the application of Section 57. The controversial detention provisions as laid down in India's anti-terror laws, not only conflict with Section 57 of the CrPC, it also runs contrary to protection against unreasonable detention. Article 22 of the Indian Constitution $1949^{32}$ provides the safeguard on arbitrary detention. Article 22(7) puts forward the proposition that the preventive detentions as applied in India are the instances of exceptions given by the Indian Parliament. ${ }^{33}$ The Terrorist and

31 Section 49(2) (b) of Indian POTA 2002; Section 43D (2) (b) of UAPA 1967

32 Article 22 of the Constitution of India covers the safeguards against arrest and detention.

(1) "No person who is arrested shall be detained in custody without being informed, as soon as may be, of the grounds for such arrest nor shall he be denied the right to consult, and to be defended by, a legal practitioner of his choice. (2) Every person who is arrested and detained in custody shall be produced before the nearest magistrate within a period of twenty-four hours of such arrest excluding the time necessary for the journey from the place of arrest to the court of the magistrate and no such person shall be detained in custody beyond the said period without the authority of a magistrate. (3) Nothing in clauses (1) and (2) shall apply (a) to any person who for the time being is an enemy alien; or (b) to any person who is arrested or detained under any law providing for preventive detention.

(4) No law providing for preventive detention shall authorise the detention of a person for a period longer than three months unless:- (a) an Advisory Board consisting of persons who are, or have been, or are qualified to be appointed nothing in this sub-clause shall authorise the detention of any person beyond the maximum period prescribed by any law made by Parliament under sub-clause (b) of clause (7); or (b) such person is detained in accordance with the provisions of any law made by Parliament under sub-clauses (a) and (b) of clause (7).

(5) When any person is detained in pursuance of an order made under any law providing for preventive detention, the authority making the order shall, as soon as may be, communicate to such person the grounds on which the order has been made and shall afford him the earliest opportunity of making a representation against the order.

(6) Nothing in clause (5) shall require the authority making any such order as is referred to in that clause to disclose facts which such authority considers to be against the public interest to disclose."

33 Article 22(7) states that: "Parliament may by law prescribe (a) the circumstances under which, and the class or classes of cases in which, a person may be detained for a period longer than three months under any law providing for preventive detention without obtaining the opinion of an Advisory Board in accordance with the provisions of sub-clause (a) of clause (4);(b) the maximum period for which any person may in any class or classes of cases be detained under any law providing for preventive detention; and (c) the procedure to be followed by an Advisory Board in an inquiry under sub-clause (a) of clause (4) Right against Exploitation." 
Disruptive Activities, 1987 ('TADA 1987') ${ }^{34}$ provided the extended periods of detention of terror suspects in India pending investigation. It was applied even after TADA's repeal and continued to be adopted and enforced until POTA $2002^{35}$ was repealed. This has dramatically changed the provision under Section 167(2) of the CrPC 1973.The section outlines the procedure to be followed in instances whenever the police officers failed to conclude their investigation within the time span of twenty hours allowed. Under such situations, it allows further detention for a particular number of days on complying with certain requirements. ${ }^{36}$

In the case of Mulund Railway Blasts, ${ }^{37}$ the Indian Supreme Court attempted to strike a balance regarding the liberties of the accused person charged in court against the national security concerns in arriving at a conclusion of the case. In cases of offenders of grave offences like those arrested under the provisions of TADA 1987 and POTA 2002, the Supreme Court was of the opinion that some leeway should be accorded to the investigating machinery to complete their investigation by extending the time needed. However, this extension was not to be given automatically provided the conditions listed in

\section{See: Section 20(4) TADA 1987}

35 Section 49(2) POTA 2002

36 Section 167(2) CrPC states: "The Magistrate to whom an accused person is forwarded under this section may, whether he has or has no jurisdiction to try the case, from time to time, authorise the detention of the accused in such custody as Magistrate thinks fit, for a term not exceeding fifteen days on the whole; and if he has no jurisdiction to try the case or commit it for trial, and considers further detention unnecessary, he may order the accused to be forwarded to a Magistrate having such jurisdiction: provided that-

(a) the Magistrate may authorise the detention of the accused person, otherwise than in the custody of the police, beyond the period of fifteen days; if he is satisfied that adequate grounds exist for doing so, but no Magistrate shall authorise the detention of the accused person in custody under this paragraph for a total period exceeding,

(i) ninety days, where the investigation relates to an offence punishable with death, imprisonment for life or imprisonment for a term of not less than ten years;

(ii) sixty days, where the investigation relates to any other offence, and, on the expiry of the said period of ninety days, or sixty days, as the case may be, the accused person shall be released on bail if he is prepared to and does furnish bail, and every person released on bail under this sub-section shall be deemed to be so released under the provisions of Chapter XXXIII for the purposes of that Chapter".

37 (2005) 7 SCC 29 (the Mulund Railway Blast case). 
the $\mathrm{Act}^{38}$ are complied with. Save for all the listed conditions being fulfilled by the authority upon their application in court, the court should reject the extension of the accused's detention period applied by the authority. ${ }^{39}$ The Court remarked:

'The report of the Public Prosecutor must satisfy the Court that the Investigating Agency had acted diligently and though there had been progress in the investigation, it was not possible for reasons disclosed to complete the investigation within the period of 90 days. In such cases, having regard to the progress of the investigation and the specific reason for the grant of extension of time, the Court may extend the period for completion of the investigation, thereby enabling the Court to remand the accused to custody during the extended period. These are compulsions which arise in extraordinary situations. [...] It is only with great difficulty that the investigating agency is able to unearth the well planned and deep-rooted conspiracy involving a large number of persons functioning from different places. It is even more difficult to apprehend the members of the conspiracy. The investigation is further delayed on account of the reluctance on the part of the witnesses to depose in such cases. It is only after giving them full assurance of safety that the police is able to obtain their statements. Thus, while law enjoins upon the investigating agency an obligation to conduct the investigation with a sense of urgency and with promptitude, there are cases in which the period

38 The conditions under section 49(2) (b) POTA 2002 states: "after the proviso, the following provisos shall be inserted, namely "Provided further that if it is not possible to complete the investigation within the said period of ninety days, the Special Court shall extend the said period up to one hundred and eighty days, on the report of the Public Prosecutor indicating the progress of the investigation and the specific reasons for the detention of the accused beyond the said period of ninety days, provided also that if the police officer making the investigation under this Act, requests, for the purposes of investigation, for police custody from judicial custody of any person from judicial custody, he shall file an affidavit stating the reasons for doing so and shall also explain the delay, if any, for requesting such police custody."

39 ibid, n.36 para 12 . 
of 90 days may not be sufficient for the purpose. Hence, the legislature, subject to certain safeguards, has empowered the Court concerned to extend the period for the completion of the investigation and to remand the accused to custody during the extended period. ${ }^{40}$

In the Mulund Railway Blast case, it was also contended by the accused that he had not been given sufficient notice of the application moved under the first proviso to Section 49(2) (b) of the POTA $2002 .{ }^{41}$ Although there is no statutory requirement to give any notice to the appellant in any specific form, the judge opined that even if there was no specific provision to this effect, fair play and principles of natural justice demand that before granting the authority to extend time to complete their investigation, the court must give notice to the accused should the accused wishes to oppose the said application. However, by bringing the accused to the court during the request for an extension of time to conclude the police investigation is sufficient for the purpose of notification of the intended application. Thus, the prerequisite of notification was required to be interpreted into the law that touches on the fairness and the principles of natural justice as decided by the Supreme Court decision in the case called Sanjay Dutt v State through CBI, Bombay ${ }^{42}$ which was cited in the Mulund Railway Blasts case with approval.

When POTA 2002 was repealed, the pre-trial detention under Section 49(2) was not abolished. In fact, when UAPA 1967 was amended in 2008, Section 43D (2) ${ }^{43}$ was similar to section 49(2) of POTA

40 ibid, n.36 para 13.

41 See section 49(2)(b) POTA 2002 (supra) n.37.

42 (1994) 5 SCC 410 see para. 3.

43 In the sub-section (2) it states: "Section 167 of the Code shall apply in relation to a case involving an offence punishable under this Act subject to the modification that in sub-section (2),

(a) the references to fifteen days, ninety days and sixty days, wherever they occur, shall be construed as references to thirty days, ninety days and ninety days respectively; and

(b) after the proviso, the following provisos shall be inserted, namely: -

Provided further that if it is not possible to complete the investigation within the said period of ninety days, the Court may if it is satisfied with the report of the Public Prosecutor indicating the progress of the investigation and the specific reasons for the detention of the accused beyond the said period of ninety days, extend the said period up to one hundred and eighty days: Provided also that if the police officer making the investigation under 
2002. Even though the amended UAPA 1967 removed the provisions pertaining to confessions made while in police custody, unfortunately, the 2008 amendments brought back many of the old provisions under POTA 2002. ${ }^{44}$ However, the good part of it was the strict criteria for discharging a suspected person taken into custody over 180 days under Section 43D (2) of UAPA 1967 received considerable attention by the Indian High Courts in some of the cases brought before them. ${ }^{45}$ The accused can no longer be kept indefinitely. If the accused furnishes bail, he must be released when the investigation is unable to finish within the time-frame allowed. Under Section 43D (2) of UAPA 1967, the merits of the case are immaterial to justify further extension of the detention period. It is observed that the court in arriving at these conclusions had turned to the court's decision on Section 167(2) of CrPC. ${ }^{46}$ The decided cases ignored the Explanation I in Section 167(2) of CrPC, which provides that irrespective of the expiration of the 60/90 days time-frame allowed (and in UAPA $90 / 180$ days), an accused person will be kept in custody if the accused person is unable to provide any bail. Although the court has moved in the right direction to shorten the length of detention of those who provide bail, it did not help those accused persons who are destitute or fail to meet the bail conditions. For example, the requirement of sureties will make the destitute helpless and continue to languish in jail. Thus, there is still no protection in UAPA 1967 for these people to be discharged on bail. On another note, if an accused person exercised his rights under Section 43D (2) of UAPA 1967 for statutory bail, but the accused custody was found to be illegal, the Indian Supreme Court has pronounced that if there was any request for extension of time for investigation being made in court later, the duration of detention could not be extended retrospectively. Otherwise, it will defeat the accused's legal right that arises on the expiry of the $90-$ day period. ${ }^{47}$

this Act, requests, for the purposes of investigation, for police custody from judicial custody of any person in judicial custody, he shall file an affidavit stating the reasons for doing so and shall also explain the delay, if any, for requesting such police custody."

"Dhawan R; India's Unlawful Activities Prevention Act (UAPA): The Return of POTA \& TADA" - Europe Solidaire Sans Frontières. (2008). Europe-solidaire. org. Retrieved from http://www.europe-solidaire.org/spip.php?article15177

45 Cases such as BK Lala v Chhattisgarh, (2012) Cri LJ 1629 para 17, Mohd. Maroof@Ibrahim \& Ors v State (12 May 2015) Delhi High Court

46 See cases like "Rajnikant Jivanlal v Intelligence Officer, Narcotic Control Bureau, New Delhi, (1989) 3 SCC 532; Union of India v Thamisharasi," (1995) 4 SCC 190.

47 See "Sayed Mohd. Ahmed Kazmi v State, GNCTD \& Ors" (2012) 12 SCC 1, para 25. 
In India, as pointed out, the difficulty of getting bail upon arrest is the most sinister form of deviation from the criminal procedural norm. As highlighted earlier, within 24 hours after arrest, an accused person ought to be brought before the magistrate court under their ordinary criminal procedure laws. Unless it appears to the presiding Magistrate that the investigation cannot be accomplished within the 24- hour' time-frame, the magistrate must discharge the accused on bail. During this preliminary stage, even though bail is not applicable outright in some serious non-bailable offences such as murder, such procedural rule is intended to be obeyed and 16 not an excuse not to grant bail. Within the 90 days, if no charge sheet is registered against the accused person, bail is ready as of right to the accused. ${ }^{48}$ Unfortunately, UAPA 1967 extends the duration up to 180 days, of which there is a possibility of the accused person being kept for 30 days under police custody while under investigation. In some cases, however, if a report submitted by the public prosecutor shows the progress of the investigation or a prima facie case is shown, the court may increase the duration to another 90 days if it is satisfied the investigation cannot be completed on time. Another striking feature of the UAPA 1967 is the denial of bail for illegal immigrants found in India who are apprehended for offences committed under the provisions of this anti-terror law. Hence, refusal of bail for immigrants under UAPA 1967 provisions called into question India's counter-terror measures as being undemocratic. Past practices in enforcing TADA 1987 and POTA 2002, have shown similar provisions where many detainees under such anti-terror laws were held in pre-trial detention for an indefinite period although there are ostensible safeguards prescribed under Article 22 of the Indian Constitution.

\section{The United Kingdom (UK)}

The UK government experiences a rich historical past in tackling acts of terrorism by using legislation. In the UK, detention without charge has been around before $9 / 11$ and has been applied against IRA in the Northern Ireland for decades. The impact of 9/11 prompted

48 Section 167 of $\mathrm{CrPC}$. 
the UK Parliament to quickly introduce another anti-terror law known as the Anti-Terrorism, Crime and Security Act 2001 (ATCSA 2001) which came into force on 14 December $2001 .{ }^{49}$ The most controversial provision in ATCSA 2001 has been the broad executive power granted to the Home Secretary to detain foreigners suspected to be engaged in terrorism activities without charge. ${ }^{50}$ Webber ${ }^{51}$ reported that from 2006 until the end of 2011 saw the duration of the detention period without charge being raised to twenty-eight days for those who were arrested for terrorism acts. In 2014, forty-four out of sixty-five persons detained under terror legislation were dealt within seven days. Besides detention without charge, the UK government's counter-terrorism strategy entails the implementation of control orders (now abolished) under the Prevention of Terrorism Act 2005 (PTA 2005). Due to the controversial nature of the order, finally, the control order was substituted with another measure known as the Terrorism Prevention and Investigation Measures Act 2011 (TPIM). Before the start of the control orders under PTA 2005, the House of Lords, in the case known as 'Belmarsh', made a decision that the power to indefinitely detain foreigners thought to be a threat to national security and to detain them without trial under Part IV of ATCSA 2001 was inconsistent with the provisions in the ECHR. ${ }^{52}$ It was decided the detention powers granted in ATCSA 2001 were prejudicial against the foreigners caught under this Act. Besides, it was disproportionate to the extent of the threat posed by these foreigners. In just three months after the courts decision in Belmarsh, the UK government enacted PTA 2005 in March 2005. The new Act was supposed to provide an alternative to the unlawful detention found in ATCSA 2001 with a two-layered control order. ${ }^{53}$ Essentially, a control order was issued to a person by imposing obligations such as curfews to prohibit or restrict that individual from engaging in terrorism-related activities. The court, in Secretary of State for the

\footnotetext{
49 Anti-terrorism, Crime and Security Act 2001. (2017). Legislation.gov.uk. Retrieved 8 January 2017 from http://www.legislation.gov.uk/ukpga/2001/24/ introduction/enacted

50 A and others v Secretary of State for the Home Department (2004) UKHL 56 (The Belmarsh case).

51 Webber, D. (2016). Preventive Detention of Terror Suspects: A New Legal Framework. Routledge.

52 See the Belmarsh case.

53 See Section 2 and 4 of PTA 2005.
} 
Home Department $v M B^{54}$ laid down the test for imposing a control order as follows:

\begin{abstract}
"Whether it is necessary to impose any particular obligation on an individual in order to protect the public from the risk of terrorism involves the customary test of proportionality. The object of the obligations is to control the activities of the individual so as to reduce the risk that he will take part in any terrorism-related activity."
\end{abstract}

Unlike the early counter-terror measures in the form of preventive detention without charge as applied in the Belmarsh, control orders are not restricted to foreigners only. The government viewed the control orders as a tool to stop and interrupt those terror suspects whom the government thought cannot be charged nor deported for lack of evidence. So, the objective of the control orders is to safeguard the overall populace from the threat pertaining to acts of terrorism by imposing burdens on these suspects who are believed to be engaged in terrorism activities (though without strong proof). Such an order is to control or prohibit these individuals from taking part in some terror activities. Control orders are theoretically civil procedures, even though a violation of such imposed responsibility by the suspect creates an unlawful offence which can be jailed up to a maximum of five years. A judge gives the control orders at the behest of the Secretary of State. In the application for the issuance of a non-derogating order in court, the onus of proof in court is not the same as the usual civil standard "on the balance of probability", but on a lower standard of "reasonable ground for suspicion" only. ${ }^{55}$ What it means here is under Section 2(1) (a) of PTA 2005 there are two limbs to be satisfied. The Secretary of State must have "reasonable grounds" for alleging the individual concerned is or has been engaged in terror activities before issuing the non-derogating orders. Unlike the derogating order under Section 4(7) (a) of PTA 2005 , the court must be satisfied on the 'balance of probabilities' that the controlled person is or has been engaged in terror activities.

54 [2006] EWCA Civ. 1140.

55 Donkin, S. (2013). "Preventing terrorism and controlling risk: A comparative analysis of control orders in the UK and Australia" (Vol. 1). Springer Science $\&$ Business Media. 
Arguably, the lesser threshold required under Section 2(1) (a) of PTA 2005 will be of great advantage to the UK government whenever a control order is sought from the court. Due to its controversial features at its inception, subsequently, in December 2011, the control order system was repealed and succeeded by TPIM.

In essence, PTA 2005 envisaged two distinct kinds of a control order. They are classified as the derogating and the non-derogating order as highlighted above. The derogating control order would be ones that are considered to disrupt the freedom and rights of the controlled person to such an extent that a derogation from Article 5 of ECHR would be required, while the non-derogating control order it is the permissible control order issued under the provision of PTA $2005 .{ }^{56}$ In short, the difference by derogation is referred to the UK's commitments as a member state of ECHR before this (Pre-Brexit), wherein Article 5 forbids the detention of a person without having the due process of law. Before a control order can be issued out, regardless of whether derogation or non-derogation, the Secretary of State has to communicate with the police officers first to figure out if indeed there is adequate proof against a suspected person for reasons of mounting a criminal prosecution. ${ }^{57}$ Through the duration of the control order, the suspected person's conduct will be regularly monitored by the police officers with a view of possible prosecution later on. ${ }^{58}$ However, according to past records, the UK government has only issued non-derogating orders. ${ }^{59}$ Therefore, it can be argued that a non-derogating control order can seriously limit a person's freedom by setting a variety of terms on a person believed to be taking part in terrorism activities. Section 1(3) PTA 2005 states:

"The obligations that may be imposed by a control order made against an individual are any obligations that the Secretary of State or (as the case may be) the court considers necessary for purposes connected with preventing or restricting involvement by that individual in terrorism-related activity."

\footnotetext{
Ibid.

Section 8(2) PTA 2005.

Section 8(4) ibid.

Donkin, S op cit. $\mathrm{n} 7$.
} 
The obligations referred to in Section 1(3) above connotes limiting the freedom of movements. Further, the suspect may be compelled to wear an electronically monitored device at the Secretary of State's assessment of each case. A terrorism-related activity is not merely restricted to the offence of the commission, preparation or instigation, ${ }^{60}$ but any behaviour in aiding or supporting including helping any suspected persons who are associated with any terrorist activity. ${ }^{61}$ Examples of such offences include writing, publishing or publishing material glorifying terrorism, openly promoting or speaking, and motivating others to commit terror acts. ${ }^{62}$

Before the repeal of PTA 2005, a non-derogating control order can be in force for twelve months and could be extended for the duration for which the Secretary of State believed as 2(1) still applied. ${ }^{63}$ Once a non-derogating order was granted, it has to be agreed to by a Judge of the High Court within seven days. ${ }^{64}$ The court's role was to decide if the recommendations brought forward by the Secretary of State were flawed. ${ }^{65}$ If it held the proposal forwarded was workable, a proceeding had to be set up. However, the suspected person could not be in court as the application was made via ex parte, nor be informed of the petition, nor provided with the opportunity to defend himself. ${ }^{66}$ If the court found faults in the Secretary of State's argument, or in the obligations recommended, the order or that specific obligation had to be set aside, or else, the order had to be approved ${ }^{67}$ Once approved, the individual in question will be conveyed the order issued against him. ${ }^{68}$ What tantamounts to defects in the Secretary of State's application in court, as PTA 2005 pointed out are that the

60 Section 1(9) a ibid.

61 Section 1(9) b-d ibid.

62 After the enactment of PTA in 2005, Terrorism Act 2006 (TA 2006) was introduced to amend the control order regime in PTA 2005. TA 2006 made new preparatory terrorism offences such as "encouragement of terrorism (sec 1), dissemination of terrorist publications ( $\mathrm{sec} 2$ ), preparation of terrorist acts (sec 5) and training for terrorism (sec 6)." These new offences allowed individuals who might otherwise have been subjected to a control order to be charged in court.

63 See section 2(4) and (6) PTA 2005.

64 Section 3(1) a and 3 (4) ibid.

65 Section 3(2) a ibid.

66 Section 3(5)(a), (b) and (c).

67 Section 3(6) ibid.

68 Section 3(9) ibid. 
concepts applicable on any typical judicial review would be used ${ }^{69}$ that is Diplock Trilogy ${ }^{70}$ on illegality, procedural impropriety and irrationality. Executive powers can be set aside by the court if they have breached fundamental rights such as the due process in any case being brought before the court. Additionally, the original nonderogating control order could be amended, both at the suggestion of the suspected person or the Secretary of State. ${ }^{71}$ Interestingly also, Section 2(9) outlined that all the obligations to be imposed do not necessarily have to be related to the offence for which the suspected person was caught initially. Effectively, this is giving the Secretary of State complete discretion to enforce more constraints. Although the control order was a civil measure imposed by the authority, an important that point needs to the highlighted here is any violation of the commitment by the suspected person in the said order is vulnerable to criminal prosecution. ${ }^{72}$

In the wake of criticism on control orders, a revised form of control order regime was subsequently introduced in 2012..$^{73}$ The new scheme was meant to be more flexible and focused on less stringent conditions than those found in the control orders, ${ }^{74}$ but critics say it was little more than "control orders lite." 75 The earlier control orders regime introduced through PTA 2005 were more constraining as terror suspects were subjected to relocation to another district away from their original places of abode and would also be placed under 16-hour curfews. Suspects can also be prevented from mixing with certain named people, using mobile phones or the internet. Under the new TPIMs, the suspects can be tagged electronically with devices and made to report regularly to the police. Thus, TPIMs relate more closely to current civil law restrictions. The aim of the measures is to have a defensive effect by interrupting the terror suspects' plans

69 Section 3(11) b ibid.

70 See "Bonner, D. (2006). Checking the executive? Detention without trial, control orders, due process and human rights. European Public Law," 12(1), 45-71.

71 Section 7(1) PTA 2005.

72 Section 9(1) stated: "A person who, without reasonable excuse, contravenes an obligation imposed on him by a control order is guilty of an offence."

73 See: Section 1 of the Terrorism Prevention and Investigation Measures Act 2011 (Chap 23).

74 Schedule 1 Part 1 ibid.

75 UK counter-terror review explained-BBC News. (2016). Retrieved from http:// www.bbc.com/news/uk-12289294 
or to alleviate police investigation. Henceforth, police officers will have a legal responsibility to ensure that the suspect's behaviour is held under regular check with the hope of bringing a criminal charge later on against the suspect. TPIMs are imposed by notice to the Secretary of State who must inter-alia be satisfied with the balance of probabilities ${ }^{76}$ that the suspect is or has been engaged in terrorism acts and thus, it is crucial to use any of the wide range of measures to safeguard the citizens from the danger of terror attacks. ${ }^{77}$ TPIMs may not exceed two years, ${ }^{78}$ but the Secretary of State must keep under review whether it is necessary to continue the measures. ${ }^{79}$ Permission from the High Court must be sought before the measures can be imposed. ${ }^{80}$ After permission is given, and the suspect is served with the notice detailing the measures, the High Court conducts a review hearing as soon as it is reasonably practical ${ }^{81}$ There is a right to appeal against any decision to vary or extend the notice, or any refusal to vary or discharge the notice. ${ }^{82}$ Besides judicial scrutiny, the Secretary of State must issue a quarterly report. ${ }^{83}$ The Secretary of State's TPIM powers is only valid for five years. ${ }^{84}$ Having considered the different preventive detention regimes above, this article can affirm that the UK's preventive detention framework has a dual-purpose approach. It permits detention for investigation and facilitate decisions about whether to charge a terror suspect ultimately. It also permits preventive detention of terror suspects without charge for up to fourteen days. Thus, the UK wields a delicate balance between security and liberty. When faced with significant actual threats and attacks, the government tilts the security side of the scale as far as it can. When prompted by the courts, the UK has retreated and responded to the findings of human rights violations by changing its laws quickly. For example, discriminating between local citizens and foreigners regarding the length of detention periods resulted in the repeal of ATCSA 2001. When the length of curfews

76 The evidential standard of "reasonable ground" under Section 3(1) of TPIM Act was amended by Section 20(1) of CTSA 2015 to "balance of probabilities".

77 Section 2(2) TPIM Act 2011.

78 Section 5 ibid.

79 Section 11 ibid.

80 Section 6 - 9 ibid.

81 Ibid.

82 Section 16 ibid.

83 Section 19 ibid.

84 Section 21 ibid. 
under control orders reached eighteen hours, and ECHR considered that period amounted to a deprivation of liberty, ${ }^{85}$ the government pulled back and reduced the curfew to sixteen hours. Unlike other comparable jurisdictions in this study, at least the UK government listened to the complaints about control orders and replaced them with TPIMs. Now, under Section 6 of TPIM, a court will scrutinise any application by the Secretary of State before any measures can be imposed on any person. In contrast with POTA 2015, PTB established under the Act, ${ }^{86}$ decides on issuing the detention orders on any suspected person without the legal scrutiny of the court. Hence, the discretionary powers conferred on the PTB appears to be broad as any decision made is not reviewable by the court. ${ }^{87}$ Meanwhile, in India, many legal challenges have been mounted in court to test the validity of their anti-terror law provisions against the constitution regarding fundamental rights protection ranging from arrest, bail and detention as discussed in the preceding paragraphs above. Therefore, it is observed that at least, in India and the UK, the courts were given the opportune time to examine if any aspects of the anti-terror provisions have degraded the Rule of Law values unlike Malaysia's POTA 2015.

Another noteworthy observation is the unique source of the legal power from where the security laws or the emergency powers are derived for the three states. In a system of government based on constitutional supremacy such as Malaysia and India, the emergency powers to pass an emergency law such as POTA 2015 affecting the safety of Malaysians can be traced to Article $149^{88}$ of the Federal Constitution. For India, Article $352^{89}$ of the Constitution empowered the President of India, as the head of the executive branch, to proclaim a state of emergency and bestow the government with

\section{SS for Home Dept. v. JJ \& others [2007] UKHL 45.}

6 Section 8 of POTA 2015.

87 Section 19 (ibid).

88 In Part XI of the Federal Constitution, Article 149 empowers the Parliament to legislate against subversion, action prejudicial to public order, etc.

89 Article 352 (1) states: "If the President is satisfied that a grave emergency exists whereby the security of India or of any part of the territory thereof is threatened, whether by war or external aggression or armed rebellion, he may, by Proclamation, make a declaration to that effect in respect of the whole of India or of such part of the territory thereof as may be specified in the Proclamation." 
the extraordinary power to make laws ${ }^{90}$ such as preventive security laws. As observed in this article, the apparent constitutional rights to enact emergency security laws seem to work paradoxically with other fundamental rights to liberty and freedom as enshrined in the constitutional framework and therefore, are perceived as repugnant to the Rule of Law values. However, in Malaysia and India, the judiciary is obligated to protect, defend and preserve the sanctity of the Constitution at all cost. In contrast to the parliamentary supremacy regime practised by the UK government, the public would have no recourse when the majority of the parliamentarians made new emergency laws such as ATCSA 2001 that curtail personal liberty rights as there are no checks and balances on the mighty Parliament under such a system. Therefore, English judges cannot simply strike down legislation even if the UK Parliament enacts unjust laws that infringe fundamental human rights. The UK Law Lords may just state it is the policy of the government and that they are not prepared to interfere. Such an approach taken by the UK courts is an acceptable norm and justified under the doctrine of parliamentary supremacy.

\section{Concluding remarks}

The nature of contemporary terrorism requires an emphasis on building a robust counter-terrorism strategy rather than the adoption of the eactive or deterrence-based approach under the ordinary criminal justice system. As a result, preventive detention has been regarded as one of the most effective tools in the counter-terrorism strategy in Malaysia, India and the UK. Although the preventive detention regime undermines human rights and disrespects the ideals of the Rule of Law such as arbitrary arrests without providing the ground for arrest and detention, Malaysia's security-based laws like ISA 1960 (repealed), SOSMA 2012 and the recent POTA 2015 show that the Acts should keep Malaysia safe from the threat to national security in times of real emergency. However, the Malaysian government has often resorted to the practice of using preventive detention measures to suppress political dissent and human rights activities in the past. Although various security-based legislations empower the law enforcement officials to investigate and detain terror suspects,

$90 \quad$ See: For e.g. Article 353 (b). 
the long-arm of the law has stretched as far as hauling up political opponents, including leaders of non-government organisations. The Malaysian government also saw mass demonstrations and other kinds of political activity as potentially undermining the interest of national security; for instance, the arrest of Bersih 2.0 leader under SOSMA $2012^{91}$ recently.

By looking at Malaysia's detention without charge regimes against other jurisdictions like those in India and the UK, the preventive detention provision by itself is problematic. For instance, the twoyear period of preventive detention (which can be extended) under POTA 2015 is not only disproportionate to the objective of the regime but also against the principles of natural justice and the Rule of Law. In fact, the security-based laws passed in Malaysia and the countries studied, the courts did sometimes attempt to support the integrity of the constitutions or safeguard the constitutional rights and freedoms. This can be seen in Abdul Ghani Haroon in Malaysia, the $A F$ in the UK and the Mulund Railway case in India.

It is to be noted that in Malaysia, there is no mechanism for independent oversight of preventive detention laws. The idea of having a safeguard mechanism is to check on the operation of the preventive detention legal framework and its measures. Therefore, it is recommended that an independent designated person or body monitor and report annually on the effectiveness of preventive detention measures under POTA 2015 and recommend proper measures or the abolition of any weak measures Based on the report and findings submitted, the government should take cognisance and respond within the time period and if necessary, to introduce changes to the detention laws if proper. Although in Malaysia and India, there is no independent oversight of the operation of terrorism legislation, it is imperative to have it in the UK, and this measure should be codified under Section 36 of the Terrorism Act 2006. ${ }^{92}$ The UK's example could serve as a model for the Malaysian government

${ }_{91}$ The Malaysian Bar - Press Release | "SOSMA Must Not Be Abused to Quell Dissent." Malaysianbar.org.my. Retrieved from http://www.malaysianbar.org. $\mathrm{my} /$ press_statements/press_release_\%7C_sosma_must_not_be_abused_to_ quell dissent.html

92 Section 36 of Terrorism Act, 2006 provides for a review of terrorism legislation in the UK, Retrieved from http://www.legislation.gov.uk/ukpga/2006/11/ section $/ 36$ 
to have a proper and proportionate exercise of preventive detention powers. In sum, this article concludes that anti-terror legislations do not adhere to the principles of the Rule of Law strictly when safeguarding national security. Instead, it has degraded the Rule of Law values.

\section{BIBLIOGRAPHY}

Abdul Ghani Haroon v Ketua Polis Negara and Anor. (2001). 2 CLJ 709.

Ateef Nasir Mulla v State of Maharashtra. (2005). 7 SCC 29 (Mulund Blast case).

A and others v Secretary of State for the Home Department. (2004). UKHL 56 (The Belmarsh case).

Anti-terrorism, Crime and Security Act 2001. (2017). Legislation. gov.uk. Retrieved from http://www.legislation.gov.uk/ ukpga/2001/24/introduction/enacted

Bonner, D. (2006). Checking the executive? Detention without trial, control orders, due process and human rights. European Public Law, 12(1), 45-71.

BK Lala v Chhattisgarh. (2012). Cri LJ 1629.

Cole, D. (2009). Out of the shadows: Preventive detention, suspected terrorists, and war. California Law Review, 97(3), 693-750.

Dhawan R. India's Unlawful Activities Prevention Act (UAPA): The Return of POTA \& TADA" - Europe Solidaire Sans Frontières. (2008). Europe-solidaire.org. Retrieved from http://www.europe solidaire.org/spip.php? article15177

Donkin, S. (2013). Preventing terrorism and controlling risk: A comparative analysis of control orders in the UK and Australia (Vol. 1). Springer Science \& Business Media.

Indian Criminal Procedure Code, 1973.

Indian Prevention of Terrorism Act, 2002.

Malaysia reveals militant link to arrests - January 23, 2002. Edition. cnn.com. Retrieved from http://edition.cnn.com/2002/ WORLD/asiapcf/southeast/01/23/malaysia.muslim.arrest/ index.html

Mohd. Maroof@ Ibrahim \& Ors v State. (12 May 2015). Delhi High Court. 
Parliamentary Debates, Dewan Rakyat. (21.6.1960). p. 1189 Operation Lalang Revisited. (2016). Aliran.com. Retrieved from http://aliran.com/oldsite/hr/js3.html

Press Releases Singapore Government Press Statement on ISA Arrests, 11 January 2002. Mha.gov.sg. Retrieved from https://www.mha.gov.sg/Newsroom/press-releases/Pages/ Singapore $\% 20$ Government $\% 20$ Press $\% 20$ Statement $\% 20$ On\%20ISA\%20Arrests,\%2011\%20January\%202002.aspx

Prevention of Terrorism Bill, a welcomed conjoined twin to ISA, says Perkasa - The Rakyat Post. (2015). Retrieved from http://www.therakyatpost.com/news/2015/03/31/preventionof-terrorism-bill-a-welcomed-conjoined-twin-to-isa-saysperkasa/Malaysian Prevention of Terrorism Act, 2015.

Rajnikant Jivanlal v Intelligence Officer, Narcotic Control Bureau, New Delhi, (1989) 3 SCC 532.

Raz, J. (1979). The authority of law (1st ed.). Oxford: Clarendon Press.

Sayed Mohd. Ahmed Kazmi v State, GNCTD \& Ors. (2012). 12 SCC.

Sanjay Dutt v State through CBI, Bombay. (1994). 5 SCC 410.

The Star Online. (2012). Security Offences Bill a positive step, says Suhakam. Retrieved from http://www.thestar.com.my/news/ nation/2012/04/16/security-offences-bill-a-positive-stepsays-suhakam/

Stigall, D. (2009). Counterterrorism and the comparative law of investigative detention. Cambria Press.

Steven Green Chapter 2: Preventive Detention and Public Security - Towards A General Model. In Harding, A., \& Hatchard, J. (Eds.). (1993). Preventive Detention and Security Law: A Comparative Survey (Vol. 31). Martinus Nijhoff Publishers.

Sunstein, C. R. (2005). Laws of fear: Beyond the precautionary principle (Vol. 6). Cambridge University Press.

SS for Home Dept. v. JJ \& others [2007]. UKHL 45.

Terrorism Prevention and Investigation Measures Act 2011.

The Malaysian Bar - Press Release |"SOSMA Must Not Be Abused to Quell Dissent.” Malaysianbar.org.my. Retrieved from http://www. malaysianbar.org.my/press_statements/press_release_\%7C_ sosma_must_not_be_abused_to_quell_dissent.html

The Constitution of India. Union of India v Thamisharasi. (1995). 4 SCC 190. 
Unlawful Activities Prevention Act, 1967. (UAPA 1967).

UK counter-terror review explained. BBC News. (2016). Retrieved from http://www.bbc.com/news/uk-12289294

Waxman, M. C. (2009). Administrative detention of terrorists: Why detain, and detain whom? Columbia Public Law Research Paper, (08-190), 08-190.

Webber, D. (2016). Preventive detention of terror suspects: A new legal framework. United Kingdom: Routledge. 